DOI 10.37882/2223-2982.2020.09.18

\title{
ОБЩЕСТВО «ПЕСНИ О РИГЕ» КАК МЕНТАЛЬНЫЙ ОБРАЗ В СРЕДНЕВЕКОВОЙ КУЛЬТУРЕ (В ИНТЕРПРЕТАЦИИ А.Я. ГУРЕВИЧА)
}

\section{"RÍGSPULA" SOCIETY AS A MENTAL IMAGE OF MEDIEVAL CULTURE (AS INTERPRETED BY A.YA. GUREVICH) \\ K. Likhomanov}

Summary: The article, using the example of the works of A.Ja. Gurevich, examines the problem of interpreting the medieval text of the Scandinavian "Rígspula", which is the bearer of the "mental image" of medieval archaic society. It was shown how the researcher uses a literary source to analyze the social consciousness of a person of the archaic era, and as a tool for cultural studies allows you to study the methods of functioning of social connections hidden from legal sources and the legitimation of hierarchy.

Keywords: A.Ja. Gurevich, "Rígspula", mental image, socio-cultural relations, prefeudal society, hierarchy, Tripartitio, Traell, Karl, Jarl.

\author{
Лихоманов Ким Владимирович \\ Соискатель, Саратовская Государственная \\ Консерватория им. Л.В. Собинова (Саратов) \\ AlisterOrm@gmail.com
}

Аннотация: В статье, на примере работ А.Я. Гуревича, рассматривается проблема интерпретации средневекового текста скандинавской «Песни о Риге», являющегося носителем «ментального образа» средневекового архаичного общества. Было показано, каким образом исследователь использует литературный источник для анализа социального сознания человека архаичной эпохи, и как инструментарий культурологии позволяет изучить скрытые от юридических источников способы функционирования социальных связей и легитимации иерархии.

Ключевые слова: А.Я. Гуревич; «Песнь о Риге»; ментальный образ; социокультурные связи; раннесредневековое дофеодальное общество; иерархия; Tripartitio; Traell; Karl; Jarl.
$\Pi$ онятие «ментального образа», или «ментальной репрезентации», давно уже вышло за предметные пределы любых гуманитарных направлений, и находится на стыке многих научных дисциплин. Изначально этот термин использовался в психологии и философии, и был связан с проблемой онтологического познания первичного мира через создание его зримого и постигаемого вторичного образа в сознании человека. В истории культуры понятие «образ» занимает особое место, особенно при изучении архаичных обществ. Ментальный образ в культуре архаичного общества является результатом моделирования окружающего мира в мифологическом сознании человека, попытки объяснения мироустройства их собственной реальности. Такой важной проблеме, как «образ общества», социальное самосознание человека, определённого социальнокультурного комплекса связей пока уделяется меньше внимания. Именно посредством «ментального образа» собственного общества человек до нового времени репрезентует социокультурные практики.

Большую роль в изучении «ментальных образов» архаичных обществ сыграли работы отечественного медиевиста А.Я. Гуревича (1924-2006), одного из самых известных учёных - скандинавистов во всём мире. Изначально занимавшийся социально-экономической проблематикой англо-саксонского раннесредневекового общества, которой посвящена его кандидатская диссертация [13], с середины 1950-х гг. он обращается к истории раннесредневековой Норвегии, работая в рамках традиционной «аграрной истории» $[13 ; 4 ; 15$ 17; 22; 2]. Именно ей и была посвящена защищённая в 1961 году докторская диссертация [19], и вышедшая в 1967 году монография «Свободное крестьянство феодальной Норвегии» [23].

Однако с середины 1960-х гг. А.Я. Гуревич всё чаще обращается к проблемам культуры, духовной жизни и ментальности скандинавов. Так, уже в первой своей монографии «Походы викингов» (1966) [20] историк посвятил небольшую главу культуре скандинавов, уделив существенное внимание скандинавским сагам как наиболее яркому её отражению. В дальнейшем историк всё чаще обращался к богатому материалу литературы, посвятив ей две небольшие монографии («История и сага» (1972) [8], «Эдда и сага» (1979) [26]). Скандинавская литература осталась, в основе своей, чужда «средиземноморскому», христианскому и античному наследию, и сохраняла на протяжении веков свою самобытность и жанровую специфичность, глубокую «сцепку» с древнегерманской архаикой, с мифом. Памятники поэзии и прозы, созданные в далёкой Исландии в X-XIII вв., до сих пор служат историкам, филологам, социологам и культурологам неисчерпаемым кладезем информации о раннесредневековой культуре и обществе.

Оригинальный творческий метод А.Я. Гуревича ярко 
проявился при анализе так называемой «Rígspula» (X XII вв.) - «Песни о Риге», которая привлекает внимание историка с самых ранних этапов его изысканий в области скандинавской истории человека. Это не случайно: «Песнь о Риге» даёт нам уникальную информацию о самосознании средневекового скандинава и об обществе, в котором он жил, что и привлекало внимание исследователя.

Цель данной статьи - рассмотрение «скандинавских» работ А.Я. Гуревича в поисках его творческой методики анализа «ментального образа» архаичного общества при изучении памятника скандинавской литературы - «Песни о Риге». Для достижения цели поставлен ряд задач: прежде всего, определить историографический контекст работ А.Я. Гуревича и выявить, какие он ставил вопросы для познания социальной реальности Скандинавии; почему он обратился именно к «Песне о Риге» как к источнику; какие методы применял к её анализу; какие основные черты ментального образа архаичного общества определил в результате своего исследования.

К сожалению, тематика, связанная с осмыслением социокультурной концепции средневекового общества А.Я. Гуревича недостаточно разработана в литературе. В общих чертах она освещается в работе С.И. Лучицкой «Очерк жизни и творчества А.Я. Гуревича (1924-2006)» [28]. Проблема человеческого содержания истории общества была освящена в работе В.П. Макаренко (2010) [29], попытку рассмотрения концепций «социальной психологии» и «ментальностей» делает Б.В. Рейфман (2013) [36], концепция «дофеодального общества» в интерпретации А.Я. Гуревича в сравнении с концепцией А.И. Неусыхина была освещена М.В. Земляковым (2014) [27]. Скандинавское наследие А.Я. Гуревича анализируется крайне редко, его исследования «Песни о Риге» вовсе не получили системного рассмотрения в историографии.

Кратко напомним, что собой представляет «Песнь о Риге». Она была найдена в составе рукописи «Codex Wormianus»', не вошедшего в «канонический» состав
«Старшей Эдды»; её датировка, место создания до сих пор не определены ${ }^{2}$. Сюжет: один из богов-асов, предположительно, Хеймдалль ${ }^{3}$ под именем Рига странствовал по берегу озера, и посетил три дома. В первом, бедном и скудном, жили Аі (Прадед) и Edda (Прабабка). Риг провёл у них три ночи: после его визита был рождён præll (Раб) [35, с. 354-356], от которого пошёл род «рабов». Во втором доме, немного богаче, жили Аfi (Дед) и Emma (Бабка), у которых после посещения Рига родился сын Karl (Муж, свободный человек), от него пошёл род свободных крестьян-бондов [35, с. 357-358]. В третьем доме, большой усадьбе, Риг посетил Faðir (Отец) и Móðir (Мать), породивших, в свою очередь, Jarl (Ярла, Князя), ставшего родоначальником рода знатных, родовитых конунгов и танов [35, с. 360]. Сын последнего, Kon, является, по всей видимости, прародителем всех верховных владык родов конунгов [35, с. 363].

Иными словами, «Песнь о Риге» отражает представления скандинавов о возникновении их общества, его трёх разрядов - рабов, свободных крестьян и знатных воинов-ярлов. По словам М. И. Стеблин-Каменского, «Песнь...» является отражением «мифологической социологии» [39, с. 17; 22]. Это разделение с давних пор привлекало внимание исследователей ${ }^{4}$.

«Песнь о Риге» сразу привлекла внимание и А.Я. Гуревича. Но в работах 1960-х гг. она фигурирует в контексте изучения стратификации общества Норвегии [16]. Впервые вопрос о «Песне о Риге» как источнике по истории культуры был поставлен А.Я. Гуревичем в работе «Походы викингов» (1966). Историк подчёркивает, что представленное в песне общественное разделение является представлением древних скандинавов о собственном социальном строе [20, с. 99], то есть фактом их социального самосознания, ментальности.

Обрисуем, в каком историографическом контексте, в котором работал историк. В теоретическом отношении большую «культурологическую» роль для А.Я. Гуревича сыграла и дискуссия о концепции «дофеодального общества», которая наиболее ярко была развёрнута в 1966

1 О самой рукописи и её происхождении: [543.

2 Как иронично замечал скандинавист М.И. Стеблин-Каменский, «...относительно «Песни о Риге» предполагали, что она была сочинена в Исландии, и что она была сочинена в Дании, и что она была сочинена в Норвегии, и что она была сочинена на Британских островах»: [38. с. 133]. Те же затруднения испытывал и Е.М. Мелетинский: [32, с. 246]. Споры вокруг датировки, места создания и культурных влияний см.: [45].

3 В самой известной эддической песне «Voluspa» (Прорицание Вёльвы) люди названы «mogo Heimdallar», «Хеймдалля дети», именно поэтому исследователи связывают его с Ригом, который также является, видимо, прародителем человечества.

4 Полная историография изучения «Песни о Риге» велика, однако мы можем выделить основные направления в изучении её «мифологической социологии». Так, известный этнограф Жорж Дюмезиль (1898-1986) увидел в ней яркое доказательство своей собственной концепции «трёх функций» индоевропейского социального строя, и даже посвятил «Песни о Риге» отдельную работу, где сравнивает «германскую социальную организацию» с индоевропейской и кельтской: [48]. Влияние кельтской мифологии на фабулу «Песни...» также с давних пор весьма популярно в историографии: [47; 56]. Другие исследователи, такие, как А. Хёйслер, считали её продуктом более поздней христианской культуры [51; также 52]. 
году А.И. Неусыхиным [33; 35]. Согласно этой теории, «дофеодальное общество» является переходным между первобытнообщинной и феодальной формациями [34, с. 45], характеризуется наличием общинной организации трудящихся субъектов, но отсутствием классовой структуры [34, с. 45], при наличии внутренней дифференциации за счёт образования земледельческой общины и выделения малых семей [34, с. 46]. Исследователь подчёркивал, что при общей собственности на землю, социальный статус человека подчёркивался его полноправием перед лицом общины, его свободой, совокупностью прав и обязанностей [34, с. 46]. Общественный строй архаичного общества, по А.И. Неусыхину, был детерминирован социально-экономическими отношениями внутри отдельно взятой общины, и зависел от полноправия сообщинника в «производственных» отношениях.

Однако А.Я. Гуревича концепт «дофеодального общества» интересовал в его культурной, ментальной составляющей. Историк ставит вопрос о границах между личностью и обществом, возможностях проявления индивида в «заданных» рамках [7], ритуальных её практиках горизонтальных связей в обществе [3], мировосприятии средневекового человека, его ментальность [3; $21 ; 25 ; 50]$, культурно-исторической психологии [9; 14; 49]. Это уже показывает, что учёный, от внешних «контуров» социально-экономических отношений развернулся к уяснению их внутреннего, культурного содержания, «ментальной сердцевине» ${ }^{5}$.

Кроме того, стоит выделить работы двух учёных-филологов, которые существенно повлияли на развитие методологии работы с текстом. Это, прежде всего, филолог-скандинавист М.И. Стеблин-Каменский, который был одним из первооткрывателей скандинавской литературы. Помимо изучения жанровых и текстологических особенностей [39], он уделял существенное внимание культуре скандинавов, их духовному миру [40], в числе прочего, в работе «Мир саги» (1971) поднимая вопрос об «образе мира», отражённом в исландских сагах [41]. Другим учёным-филологом, разрабатывающем проблемы древнескандинавской культуры, был Е.М. Мелетинский. Большое значение имеет его работа «Скандинавская мифология как система» (1973) [31], которая была посвящена реконструкции космогонической системы, ярко отображённой в литературе. Это показатель того, что А.Я. Гуревич трудился в новом, зарождающемся тренде анализа мировосприятия и реконструкции «ментальных образом» архаичных культур. Как и, впоследствии, Е.М. Мелетинский в своей «Поэтике мифа» [30], так и А.Я. Гуревич испытают определённое методологическое влияние структурализма, направления, которое изучает общество и культуру как системы универсальных структур-«знаков». Идеи структурализма, так же, как и интерес к терминологии во многом были продуктом взаимодействия также и с «Тартуской школой» семиотики Ю.М. Лотмана, с чьим сборником - «Труды по знаковым системам» - А.Я. Гуревич активно сотрудничал в 1970-е гг.

Большое влияние на методологию историка оказало и наследие французской школы «Анналов», поставившей во главе исследования «ментальность», то есть «мировидение» общественного человека Средневековья. Определяющую роль в социо-культурных исследованиях А.Я. Гуревича играли идеи Марка Блока, развивающего идеи примата изучения «социальной целостности», в рамках которой «ментальность» становилась своего рода коллективной репрезентацией коммуникации индивидов, наиболее ярко выраженной в повседневных, обыденных, «неотрефлексированных» практиках [См. 1, с. 81-85; Также: 42, с. 66-67]. Вторым по значимости «анналистом» становится наследник Блока, Жак Ле Гофф, с его идеями «l'autre Moyen Age», «другого Средневековья», который отличался ярко выраженным антропологическим подходом к истории. Повседневная жизнь, системы поведения, историческая психология - всё это стало центром внимания его концепции «ментальностей», которая, так же как и в интерпретации А.Я. Гуревича, постулировала изучение «картин мира», или, «l'imaginaire», то есть «воображаемого». Принципиальное сходство между двумя историками заключается в их внимании к фактам коллективного самосознания и общим формам мировидения [См.: 54].

В теоретических работах второй половины 1960-х гг. А.Я. Гуревич ставит целью «построение целостной... социо-культурной модели» [10] средневекового общества, которую полагает возможным сконструировать из следующих компонентов: «модель мира», создаваемая членами данного общества в прочессе их сочиальной практики, каковы нормы поведения, моральные ченности, общественные идеалы, доминирующие в данном обществе» [7, с. 385]. Иными словами, основными задачами историка становится изучение представлений людей средневековья об обществе, которые они формируют в ходе коммуникаций, воспроизводя из поколения в поколение социальные практики, а также скрепляющие их ментальные установки и элементы социальной психологии. То есть, проблемой исследования у А.Я. Гуревича становится ментальный образ общества, который сформирован в той или иной системе социокультурной коммуникации 6 . Почему именно на этом этапе, после

\footnotetext{
5 О различиях концепций А.И. Неусыхина и А.Я. Гуревича см.: [37].

6 К примеру, коммуникационные практики в облике «обмена дарами» в архаичном обществе были им прослежены в работе «Богатство и дарение у скандинавов в ранее Средневековье»: [3].
} 
многих лет изучения социокультурных аспектов германской архаики, возникает такая потребность в изучении «Песни о Риге»?

В самой известной монографии историка, «Категориях средневековой культуры» (1972) [12], ментальный образ общества человека средневековья, охарактеризованный при рассмотрении «категорий культуры», стал стержнем концепции построения «моделей мира», в свою очередь ставших основой глобальной «картины мира» архаичного общества. В основе подхода А.Я. Гуревича лежит изучение двух диахронных культурных пластов архаичной германской и средиземноморской христианской цивилизаций, в рамках которых исследовались упомянутые «категории»: «пространство и время» [12, с. 43-131], «право» [12, с. 133-153], «богатство» [12, с. 194-204, 213-223]. Среди «категорий» были и «социо-культурные коммуникации», где социальные роли расценивались как результат воспроизведения ментальных коммуникационных практик. Характеристика архаичного скандинавского общества как социальнокультурной целостности в этой работе ещё не присутствует. Материал для неё он и нашёл в процессе рассмотрения «Песни о Риге». И тотчас, вдогон «Категориям...» он публикует небольшую статью «К толкованию «Песни о Риге» $[11]^{8}$. В этой работе он выделил в качестве главного вопрос о том, насколько функциональное членение общества отражает самосознание человека средневековья [11, с. 159].

Прежде всего, А.Я. Гуревич рассматривает общие контуры скандинавского дофеодального общества. Скандинавские памятники права дают в своих формулах разделение на Tegn и Traell, то есть на «свободных» и «несвободных», «Песнь о Риге» языком символов и эстетических понятий показывает «ментальный образ» этих страт. Traell резко отличается от двух других родов, как пишет историк, «Песнь о Риге» видит в рабе низшее существо, примитивное, грубое и отталкивающее как интеллектуально, так и физически» [11, с. 171], в отличие от «благородных» образов его свободных сородичей; чёрный цвет, символизирующий «несвободу», противопоставляется ярким краскам белого цвета Jarl и красного - Karl [11, с. 168]. Более того, как подчёркивает А.Я. Гуревич, это противопоставление связано не с «разделением труда» на «чёрный и белый», по его толкованию, «в варварском обществе труд - почтенное занятие» [11, с. 172]. Историк приводит аргументы из скандинавских памятников права, по нормам которых раб - низшее существо, но по иной причине. По мнению А.Я. Гуревича, «рабы... лишённые свободы, чувства человеческого достоинства, находились вне общества и противостояли одинаково и знатным и бондам...» [11, с. 171]. Рабы, конечно же, являлись людьми, на это указывает их происхождение от Рига, но они вне рода, семьи и odal ${ }^{9}$, и потому не имеют прав свободного человека. Traell является низшим элементом в иерархии общества, точнее - не обладает полноправием в социо-культурной коммуникации.

В этих рассуждениях проявляется прежде всего смена акцентов: историк, находясь в рамках концепции «дофеодального общества», делает упор не на «троичность» структуры общества, а на «двоичность», то есть говоря не просто разделение «раб-карл-ярл», а указывая на бинарную оппозицию «свободный - несвободный» [11, с. 167-168]. Такое противопоставление характерно для структуралистской теории, наравне с оппозициями «верх/низ», «чёт/нечет», «мужчина/женщина». Однако стоит отметить, что, например, Е.М. Мелетинский, даже рассматривая бинарные оппозиции мифологического социогенеза, не привлекает подобную структуру в своём исследовании [30. с. 199-201]. Историки-марксисты, привлекающие структурализм в качестве эмпирического метода, рассматривают подобную оппозицию в классовом смысле, в смысле существования микросистемы «господин/раб», как, к примеру, Е.М. Штаерман [44. с. 30]. Как мы видели, оппозиция «свободный - несвободный» у А.Я. Гуревича имеет иной характер. В скандинавском обществе, по его мнению, это противопоставление «свободных» членов общества, включённых в сеть социальных отношений и тех, кто не являлся их полноправным участником. Подобная оппозиция близка к характеристикам «дофеодального общества» А.И. Неусыхина.

Полноценными участниками общественных отношений являются Jarl и Karl, знатные ярлы и свободные крестьяне - бонды, так как им свойственно соблюдение всей совокупности социальных практик и норм поведения, принятых в обществе, этических норм и ценностей. Напомним, что согласно постулатам теории «дофеодального общества» знать и бондов, согласно постулатам теории «дофеодального общества», разделяло имущественное расслоение и выделение зажиточной верхушки процессе разложения общинной собственности [34, с. 46]. А.Я. Гуревич в раннесредневековой Норвегии не нашёл распространённого отчуждения земли и имущественного расслоения [23, с. 143-145; 18, с. 264], следовательно, резкого имущественного разрыва, но

7 «сословно-корпоративными были не только его права, но и самая его внутренняя природа, структура его сознания и способ его поведения» [3. с. 163].

8 В монографии «Норвежское общество в раннее Средневековье» (1977) эта статья присутствует в виде главы, с незначительными стилистическими изменениями, и подробным пересказом «Песни о Риге».

9 Комплекс родственных отношений, в частности относящийся к земельной собственности 
нашёл прослойку знати, имеющую особый статус, закреплённый в законодательстве и социальной жизни [6].

Karl, «бонды - землепашцы», по мнению А.Я. Гуревича, и Traell, между собой не равны, пусть даже и те, и другие занимаются физическим трудом [11, с. 186-189]. «Песнь о Риге», помимо символического выделения физического облика и цвета кожи, чётко разводит сферу деятельности karl и грубый труд рабов. Karl «быков приручал / и сохи он ладил, / строил дома, / возводил сараи, / делал повозки и землю пахал» [35, с. 357], то есть занимался важным и почётным трудом, требующим значительных умений. Traell же «удобряли поля, / строили тыны, / торф добывали / кормили свиней, / коз стерегли» [35, с. 356], в общем, выполняли грубую, «чёрную» работу, не требующую навыков, но лишь физических усилий.

Наиболее важное место древний автор выделяет роду Jarl [11, с. 169], ведь именно он, по сюжету поэмы, стал учеником Рига ${ }^{10}$, который передал ему свой статус и сопутствующие ему умения - признаки: «стал рунам учить / сыном назвал его / дал своё имя / дал во владенье / наследные земли / наследные земли / селения древние» [35, с. С. 361]. Сын же Jarl, Kon, полностью унаследовал от деда и знание рун, и воинские качества [35, с. 362-363]. Это позволило ему, по всей видимости, впоследствии стать, собственно, konungr - правителем. А. Я. Гуревич отмечает, что «конунг - обладатель сверхъестественного могущества, потомок и любимец богов» [11, с. 170], то есть его знатность, родовитость в глазах скандинавов проистекала из «факта» происхождения от богов-асов, что сакрализировало само его происхождение, закрепляло в мифологическом сознании скандинавов особый статус знати. Историк делает предположение, что «Песнь о Риге» была создана для прославления одного из конунгов, для чего требовалось, как это принято в скандинавском обществе, проследить его род до условной эпохи «культурных героев». Так, в ментальном образе общества закреплялся статус родовой знати.

А.Я. Гуревич пытается глубже охарактеризовать эту схему, опираясь на свой собственный опыт анализа архаичного строя. Как он показал в более ранней работе, «знатные, рядовые свободные... рабы различались между собой происхождением и правами, которыми они обладали, или которых были лишены» [18, с. 273]. Учёный делает акцент на происхождении человека, принадлежности его к определённой «касте». В статье «К толкова- нию «Песни о Риге» проблема разворачивается из сферы социально-экономической в плоскость самосознания и культуры. А.Я. Гуревич с самого начала акцентирует внимание на представление о «родовитости» бонда, носителя общинных прав odal, это выделяется им постоянно, поскольку даёт ключ к пониманию признаков статусности, за счёт знатности предков. Принадлежность к определенным родам перво-людей важна и в обществе «Песни о Риге», где, по словам историка, «даются длинные перечни имён членов родов Трэля, Карла и Ярла, причём все они содержат определённую сочиальную, производственную, физическую или моральную характеристику» [11, с. 169]. Иными словами, по мысли А.Я. Гуревича, человек наследовал от предков не только землю, но и целый ряд социокультурных характеристик, модели поведения, то есть ту самую «ментальность», о которой говорили Л. Февр и Ж. Ле Гофф. как «социальное поле». А.Я. Гуревич пытается уловить специфические черты этих социокультурных пространств.

Какие же культурные составляющие, по мнению А.Я. Гуревича, можно найти среди признаков, позволяет определять и знать, и крестьян как Tegn, «свободных»? Как ясно, исключительно ментальные, мировоззренческие категории: «свободу и полноправие, выраженные с разной степенью полноты, этические и культурные ченности... Чувство личного достоинства и независимости...» $[11, \text { с. 171] }]^{11}$. Учёный делает важный культурологический вывод: представление о социальных стратах, связанных с одним божественным первопредком, «культурным героем», закрепляло в мифологическом сознании «дофеодального общества» систему твёрдо разграниченного социума, социо-культурные практики которого воспроизводились в родовых коллективах. Социальная коммуникация теперь наполнялась новым, культурно-антропологическим содержанием.

Методы классической социально-экономической истории, «аграрной школы», не могли раскрыть всю полноту богатства содержащихся там сведений, не могли показать всей специфики социального сознания людей средневековья. Методы социально-культурной истории, анализ мировосприятия человека, его «картины мира», ментального образа окружающей его действительности, позволили учёному проникнуть за расплывчатые формулировки памятников права и понять культурные смыслы представлений средневековых скандинавов об их собственном обществе, систему, на которой базиро-

10 Риг, таким образом, становится «первопредком-демиургом», «культурным героем», который «моделирует первобытную общину в целом», по словам Е. М. Мелетинского: [30, с. 178] В данном контексте ясно, что здесь лишь один из родов общины становится полноценным наследником мифологического первопредка.

11 Современный историк А. А. Хлевов так описал этот тип: «Тип свободного и равноправного домовладельца, участника ополчения и индивидуального бойца, потенциального члена дружины выдающегося вождя, главы своего семейства, корабела и путешественника, способного к рискованным и авантюрным предприятиям»: [43]. 
вался их непосредственный социальный опыт ${ }^{12}$.

Однако здесь хотелось бы отметить и обратное влияние. Учёные-культурологи редко оперируют понятиями социальной и экономической реальности, рассматривая духовную сторону жизни общества отдельно от их повседневной и материальной жизни. А.Я. Гуревич, расширяя исследовательское пространство, привнёс не только методы изучения истории культуры в классическую «аграрную историю», но и показал важность понимания экономической и правовой стороны жизни для изучения культуры раннесредневекового архаичного общества, указывая на неразрывность и взаимозависимость двух сторон жизни при реконструкции его «ментального образа».

Скандинавское tripartitio закрепляло в сознании мифологическую картину происхождения общества, которая детерминировала определённые социальные роли, и придавала им сакральную, культурную легитимность. Однако плотное соединение с мифологической традицией Скандинавии, его переплетение с германскими правовыми нормами и воспроизводство социо-культурных практик внутри родового коллектива, которые, в конечном счёте, получили своё окончательное выражение в трёх ветвях потомков богов-асов, является, по мнению историка, подтверждением, что «Песнь о Риге» имеет более глубокие корни. «Песнь о Риге» остаётся для А.Я. Гуревича памятникам архаичной германской культуры, и отображает не наступающую христианскую модель ментальности, но «отпечаток» более древних пластов социального самосознания, системы, которая закрепляла несколько уровней горизонтальных связей в обществе. Таким образом, памятник скандинавской литературы, архаичной германской культуры, стал ярким свидетельством существования особого ментального образа общества людей Средневековья, как основой их социокультурных практик.

1. Блок М. Апология истории. М., 1976.

2. Гуревич А.Я. Архаичные формы землевладения в юго-западной Норвегии VIII - Х вв. // Учён. зап. Калининградского пед. ин-та. Калинин,1962. Т. 26. С. 135-166.

3. Гуревич А.Я. Богатство и дарение у скандинавов в раннее средневековье // Средние века. М., 1968. Вып. 31. С. 180-198.

4. Гуревич А.Я. Большая семья в северо-западной Норвегии в раннее средневековье (по судебнику Фростатинга) // Средние века. М., 1956. Вып. 8. С. 7096.

5. Гуревич А.Я. Время как проблема истории культуры // Вопросы философии. М., 1969. №3. С. 105-116.

6. Гуревич А.Я. Генезис феодализма в западной Европе // Избранные труды. Древние германцы, викинги. СПб. 2007.

7. Гуревич А.Я. Индивид и общество в варварских государствах // Проблемы истории докапиталистических обществ. М., 1968. Кн. 1 С. 384-424.

8. Гуревич А.Я. История и сага. М., 1972.

9. Гуревич А.Я. История и социальная психология: источниковедческий аспект // Источниковедение. Теоретические и методологические проблемы. М., 1969. С. 384-426.

10. Гуревич А.Я. К дискуссии о докапиталистических общественных формациях: формация и уклад // Вопросы философии. М., 1968. №2. С. 129.

11. Гуревич А.Я. К толкованию «Песни о Риге» // Скандинавский сборник. Вып. 18. Таллинн., 1973. С. 159-174.

12. Гуревич А.Я. Категории средневековой культуры // Избранные труды. Средневековый мир. СПб., 2007.

13. Гуревич А. Я. Крестьянство Юго-Западной Англии в донорманнский период: (Проблема образования класса феодально-зависимых крестьян в Уэссексе в VII - начале XI в.): Автореф. дис... канд. ист. наук. М., 1950.

14. Гуревич А.Я. Некоторые аспекты изучения социальной истории: (общественно-историческая психология) // Вопросы истории. М., 1964. №10. С. 51-68.

15. Гуревич А.Я. Норвежская община в раннее средневековье // Средние века. 1958. Вып. 11. М., С. 5-27.

16. Гуревич А.Я. Норвежские бонды в ХІ-ХІІ вв. // Средние века. Вып. 26. М., 1964. С. 3-26.

17. Гуревич А.Я. Норвежские лейлендинги в X - XI вв. (К вопросу о феодально-зависимом крестьянстве в Норвегии) // Скандинавский сборник. Таллин, 1963. Вып. 7. С. 7-43.

18. Гуревич А.Я. 0 некоторых особенностях норвежского феодализма // Скандинавский сборник. Вып. 8. Таллин, 1964.

19. Гуревич А.Я. Очерки социальной истории Норвегии в IX-XII вВ. Автореф. дисс. . . д-ра ист. наук. М., 1961.

20. Гуревич А.Я. Походы викингов. М., 1966.

21. Гуревич А.Я. Представления о времени в средневековой Европе // История и психология. М., 1971. С. 159-198.

12 В своей последней статье «Феодализм перед судом историков, или о средневековой крестьянской цивилизации» (2004) А.Я. Гуревич вновь обращается к «Песне о Риге». Не добавив ничего нового к анализу, он, тем не менее, более чётко сформулировал понятие «ментального образа»: «Перед нами - не то, что было «на самом деле», а то, что создавалось в сознании средневековых скандинавов. Иными словами, наличо не «реальное отражение» общественного бытия, но его образ, формировавшийся фантазией людей, принадлежавших этому обществу...»: [24, С. 879]. 
22. Гуревич А.Я. Свободное крестьянство и феодальное государство в Норвегии в X - XII вв. // Средние века. М., 1961. Вып. 20. С. 3-31.

23. Гуревич А.Я. Свободное крестьянство феодальной Норвегии. М., 1967.

24. Гуревич А.Я. Феодализм перед судом историков, или о средневековой крестьянской цивилизации // Гуревич А.Я. История - нескончаемый спор. М., 2006. С. 843-889.

25. Гуревич А.Я. «Что есть время?» // Вопросы литературы. М., 1968. №11. С. 151-174.

26. Гуревич А.Я. «Эдда» и сага. М., 1979.

27. Земляков М.В. А.И. Неусыхин и его концепция переходного периода: восприятие и интерпретации // Вестник Православного Свято-Тихоновского Гуманитарного Университета. Серия ІІ История. История Русской Православной Церкви. М., 2014. Вып. 56. № 1. С. 113-136.

28. Лучицкая С.И. Очерк жизни и творчества А.Я. Гуревича (1924-2006) // Образы прошлого. Сборник памяти А.Я. Гуревича. СПб., 2011. С. 7-36.

29. Макаренко В.П. А.Я. Гуревич contra Фернан Бродель: проблема расхождения взглядов // Южно-Российский форум: экономика, социология, политология, социально-экономическая география. 2010. № 1 (1). С. 54-76.

30. Мелетинский Е.М. Поэтика мифа. М., 1976.

31. Мелетинский Е.М. Скандинавская мифология как система. М., 1973.

32. Мелетинский Е.М. «Әдда» и ранние формы эпоса. М., 1968.

33. Неусыхин, А.И. Дофеодальный период как переходная стадия развития от родоплеменного строя к раннефеодальному (на материале истории Западной Европы раннего средневековья) // Вопросы истории. М., 1967. № 1. С. 75-87.

34. Неусыхин А.И. Дофеодальный период как переходная стадия развития от ро-доплеменного строя к раннефеодальному (тезисы доклада) // Средние века. Вып. 31. М., 1968. С. 45-48.

35. Песнь о Риге // Старшая Эдда. СПб., 2011. С. 354-356. (пер. А. Корсуна).

36. Рейфман Б.В. «Возможные миры» новоевропейской культуры: по поводу спора о личности между Л.М. Баткиным и А.Я. Гуревичем // Вестник Российского государственного гуманитарного университета. Серия «Философские науки. Религиоведение». М., 2013. №11. С. 203-211.

37. Сергеева Т.Д. Концепция «дофеодального периода» в творчестве А.И. Неусыхина // История и историки. Историографический ежегодник. 1982-1983. М., 1987. С. $225-244$

38. Стеблин-Каменский М. И. Древнескандинавская литература // Стеблин-Каменский М.И. Труды по филологии.СПб., 2003.

39. Стеблин-Каменский М.И. Исландская литература. Л., 1947.

40. Стеблин-Каменский М.И. Культура Исландии. Л., 1967.

41. Стеблин-Каменский М.И. Мир саги. Л., 1971.

42. Трубникова Н.В. Французская историческая школа «Анналов». М., 2016.

43. Хлевов А.А. Предвестники викингов. М., 2002.

44. Штаерман Е.М. К проблеме структурного анализа в истории // Вопросы истории. М., 1968. №6., С. 20-37.

45. Amory F. The Historical Worth of Rígspula // Alvissmal. №10. 2001. P. 3-20.

46. Bagge S. Old Norse Theories of Society. From Rígspula to Konungs skuggsiá // Jens Eike Schnall und Rudolf Simek (Hrg.): Studia Medievalia Septentrionalia, Band 5: Speculum regale. Der altnorwegische Königsspiegel (Konungs skuggsjá) in der europäischen Tradition. Verlag Fassbaender, Wien 2000, S. 7-45.

47. Dronke U. The Poetic Edda. Bd. 2. Mythological Poems. Oxford, 1997. P. 202-208.

48. Dumézil G. The Rígspula and Indo-European Social Structure // Gods of the Ancient Northmen. Berkeley. 1973. P. 118-125.

49. Gurjewitsch A. Geschichte und Sozialpsyhologie // Sowjetwissenschaft. Gesellschafts-wissenschaftliche Beitrage. 3 Marz, Berlin. 1965. S. 323-336.

50. Gurevich A. Space and time in the Weltmodell of the Old Scandinavian Peoples // Medieval Scandinavia. Odense, 1969. Vol. 2. P. 42-53.

51. Heusler A. Heimat und Alter der eddischen Gedichte: Das isländische Sondergut // Heusler A. Kleine Schriften, Vol. 2. Berlin. 1969.

52. Hill T. Rígspula: Some Medieval Christian Analogues // Speculum. №61. P. 79-89.

53. Johansson K.G. Rígspula och Codex Wormianus: Textens funktion ur ett kompilationsperspektiv // Alvissmal. №8. 1998. P. $67-84$.

54. Scholze-Irrlitz L. Moderne Konturen historisher Anthropologie. Eine vergleichende Studie zu den Arbeiten von Jacques Le Goff und Aaron J. Gurjewitsch. Frankfurt, 1994.

55. Young J. Does Rígspula Betray Irish Influence? // Arkiv för nordisk filologi. №49. P. 97-107.

(c) Лихоманов Ким Владимирович (AlisterOrm@gmail.com).

Журнал «Современная наука: актуальные проблемы теории и практики» 